\title{
Ammonium regeneration in the Scotia-Weddell Confluence area during spring 1988
}

\author{
Leo Goeyens ${ }^{1}$, Paul Tréguer ${ }^{2}$, Christiane Lancelot $^{3}$, Sylvie Mathot ${ }^{3}$, Sylvie Becquevort ${ }^{3}$, \\ Jean Morvan ${ }^{4}$, Frank Dehairs ${ }^{1}$, Willy Baeyens ${ }^{1}$ \\ ' Vrije Universiteit Brussel, Laboratorium voor Analytische Chemie, Pleinlaan 2, B-1050 Brussell, Belgium \\ ${ }^{2}$ Université de Bretagne Occidentale, Institut d'Etudes Marines, Avenue Le Gorgeu 6, F-29287 Brest Cedex, France \\ ${ }^{3}$ Université Libre de Bruxelles, Groupe de Microbiologie des Milieux Aquatiques, Boulevard du Triomphe, \\ B-1050 Bruxelles, Belgium \\ 'Université de Rennes, Ecole Nationale de Chimie de Rennes, Avenue du Général Leclerc, F-35700 Rennes, France
}

\begin{abstract}
The presence of large ammonium stocks and the related enhanced quantities of microheterotrophs in the Scotia-Weddell Confluence area indicate the importance of ammonium remineralization processes there. Maximal ammonium concentrations in the marginal ice zone amounted to more than $2 \mu \mathrm{mol} \mathrm{N}{ }^{-1}$ and remineralization rates in this zone were consistently higher than those measured in the adjacent open ocean and permanently ice-covered zones. At one station, characterized

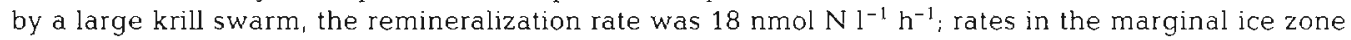

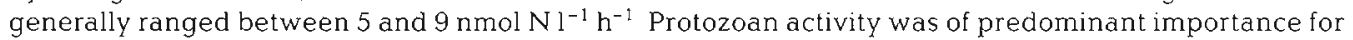
the remineralization process; only after the krill event was a very high bacterial activity observed. The presence of krill does not contribute in a direct way to the ammonium pool, but probably initiates the bacterial breakdown activity in algal debris and faecal pellets. The increased remineralization leads to enhanced availability of ammonium in the water and to decreased f-ratios for phytoplanktonic nitrate assimilation. Nevertheless, nitrate uptake represented at least $30 \%$ of inorganic nitrogen assimilation, significantly higher than values measured for oligotrophic systems.
\end{abstract}

\section{INTRODUCTION}

The role of the Southern Ocean in the global biogeochemical carbon cycle and its potential influence on the global climate is nowadays a leading concern in oceanographic research. In this regard the concepts of new production (here defined as nitrate-based primary production) and regenerated production (ammoniumbased primary production), introduced by Dugdale \& Goering (1967), are of particular interest for the sequestration of carbon in the deep ocean (Eppley \& Peterson 1979). New production sets upper limits to export rates of organic matter from the euphotic layer; regenerated production, on the other hand, is based on nutrients recycled in the ocean surface layer and makes a negligible contribution to export to deeper layers and sediments.

In the Southern Ocean the dissolved inorganic nitrogen pool is mainly nitrate, with ammonium representing ca 2 to $10 \%$. Surface nitrate concentra- tions are usually around $25 \mu \mathrm{mol} \mathrm{N} \mathrm{N}^{-1}$ (Sharp 1983). Earlier investigations in the Indian Ocean sector of the Southern Ocean (Slawyk 1979, Le Jehan \& Tréguer 1983, Probyn \& Painting 1985), in the Ross Sea (Biggs 1982, El-Sayed et al. 1983, Nelson \& Smith 1986), and in the Weddell and Scotia Seas (Olson 1980, Glibert et al. 1982a, Rönner et al. 1983, Koike et al. 1986) indicated the temporal importance of ammonium stocks in the water. Especially during late spring and summer, ammonium concentrations can reach 2

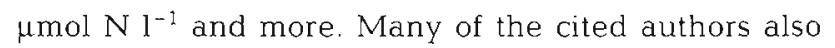
argue that Southern Ocean phytoplankton meets most of its nitrogenous needs by taking up ammonium, despite higher ambient concentrations of nitrate. The relative contributions of new and regenerated nitrogen to primary production are commonly estimated by the f-ratio (the ratio between nitrate and total inorganic nitrogen uptake rates). An average f-ratio for the whole Southern Ocean, as estimated from these studies, amounts to less than 0.5. The data show, 
however, an extremely great variability, ranging from 0.07 (Koike et al. 1986) to 0.98 (Collos \& Slawyk 1986). In a recent study Smith \& Nelson (1990) found clear regional variations in $\mathrm{f}$-ratios for the Southern Ocean, open sea areas being characterised by lower values $(0.22<$ f-ratio $<0.54)$, ice-associated ecosystems by higher values $(0.48<$ f-ratio $<0.72)$. However, Collos \& Slawyk (1986) measured f-ratios ranging from 0.35 to 0.98 in the Indian Ocean sector of the Southern Ocean. Their values were not considered in the discussion by Smith \& Nelson (1990).

Goeyens et al. (1991) observed average f-ratios of 0.47 and 0.57 respectively for the open sea area and for the marginal ice zone of the Scotia-Weddell sector. Additionally, these authors showed a decrease in $f$ ratio from 0.78 to 0.30 in the marginal ice zone during November and December 1988. Simultaneously the importance of pico- and nanoplanktonic organisms in the water increased and heterotrophic organisms were shown to contribute largely to this plankton population (Becquevort et al. 1991). Budget calculations for the Weddell Sea marginal ice zone indicate that about $70 \%$ of the net primary production is assimilated in the microbial food web, composed of bacterioplankton, heteronanoflagellates and protozoa (Lancelot et al. 1991a). This concept of an alternate carbon pathway at the lower trophic levels of the Antarctic system was described earlier by Hewes et al. (1985). It stresses the ecological importance of heterotrophic microorganisms for ammonium regeneration, as this process induces a shift in the relative proportions of nitrate and ammonium available to phytoplankton. Smith \& Harrison (1991) suggest that for different polar regions the relationship between the f-ratios and the ambient ammonium concentrations indicates, as a general trend, a reduction in $\mathrm{f}$-ratio with increasing ammonium concentrations. Supplementary information on the relation between nutrient utilization and availability is obtained from relative preference indices (RPI) - the ratios of the uptake fraction to the concentration fraction for single nitrogenous nutrients (McCarthy et al. 1977). For a number of Southern Ocean studies ammonium is consistently found to be the preferred nutrient (Smith \& Harrison 1991). These considerations and previous observations highlight the central position of ammonium in the nitrogen cycle of this ecosystem. We present data on ammonium distributions and related uptake and remineralization processes in the ScotiaWeddell Confluence area during the sea ice retreat in 1988 (EPOS LEG 2 cruise) and provide evidence for the importance of heterotrophic microorganisms as ammonium producers in this sector of the Southern Ocean

\section{MATERIAL AND METHODS}

Sampling. Data were collected at 44 hydrographic stations in the Scotia-Weddell Confluence Area in November and December 1988, during the EPOS LEG

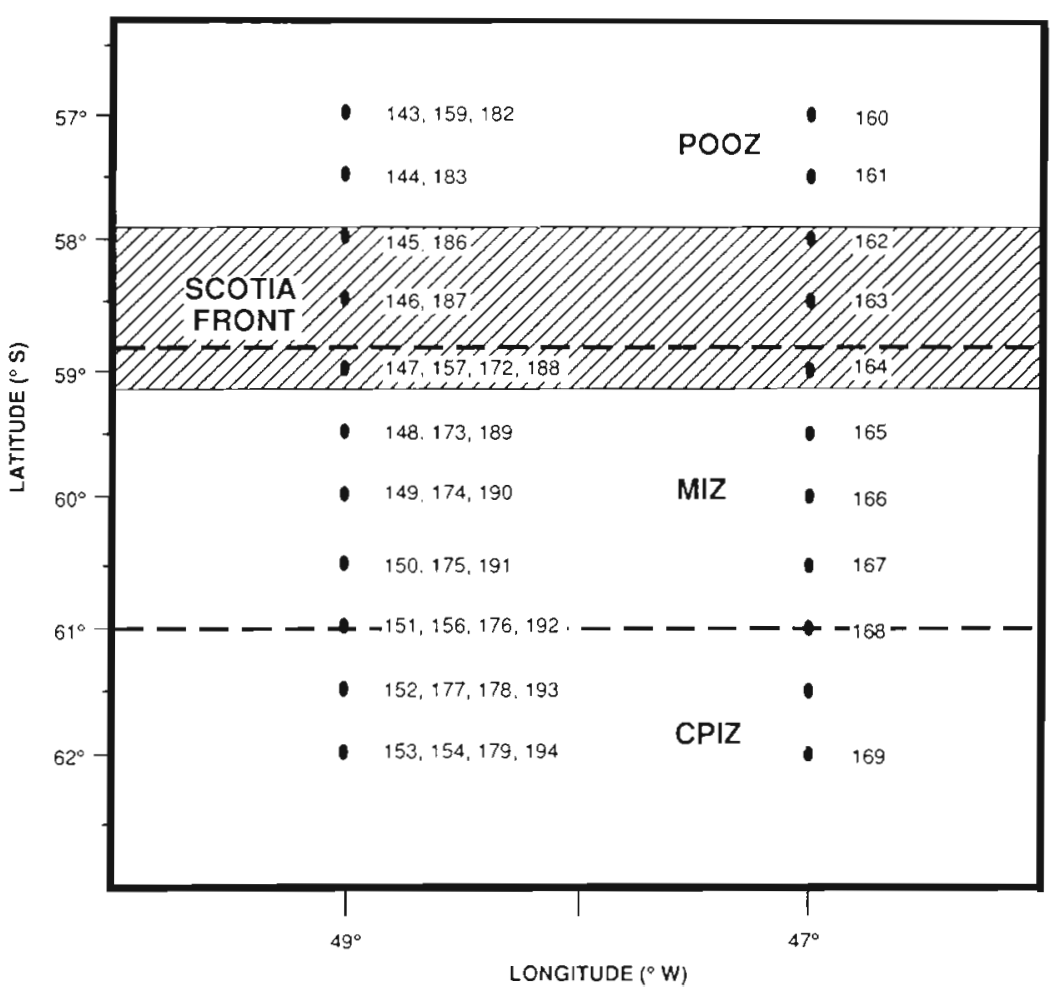

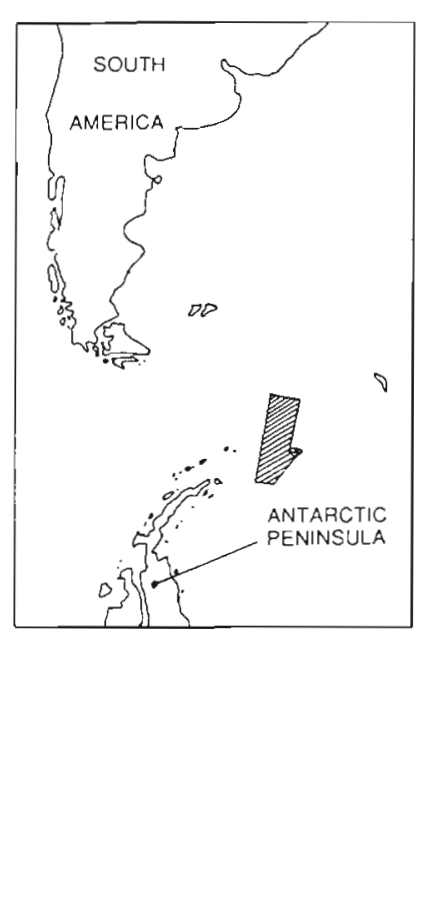

Fig. 1 Station positions during the EPOS LEG 2 cruise 
2 cruise on board RV 'Polarstern'. The studied area was within 57 to $62^{\circ} \mathrm{S}$ and 47 to $49^{\circ} \mathrm{W}$; the cruise track was conceived in such a manner that the ship steamed 4 times through the Scotia Front along $49^{\circ} \mathrm{W}$ and once along $47^{\circ} \mathrm{W}$ (Fig 1). The transects along the $49^{\circ} \mathrm{W}$ meridien were: $W 1$, Stns 143 to 153 (Nov 26 to 30 ); $W 2$, Stns 154 to 159 (Nov 30 to Dec 12); W3, Stns 172 to 179 (Dec 20 to 24); and W4, Stns 182 to 194 (Dec 27 to 31). The eastern transect along $47^{\circ} \mathrm{W}$, denoted Transect $E$, consisted of Stns 160 to 169 (Dec 13 to 17 ).

Physical, chemical and biological variables. Salinity, temperature, pressure, oxygen, nutrient and chlorophyll concentrations were measured at every station; the collected results are given in EPOS LEG 2 (1989). Samples for nutrient analysis were collected either from the 12 l Niskin bottles, mounted on the CTD rosette, or from 30 l Niskin bottles, used for total suspended matter filtration and for productiondissolution experiments. Nitrate plus nitrite was measured with a Technicon Autoanalyzer II according to the technique of Tréguer \& Le Corre (1975). Millipore MilliQ water was used as zero level; the calibration was carried out against 4 potassium nitrate standards

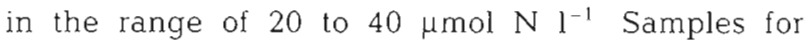
ammonium determination were immediately fixed by addition of the reagents and stored at ambient temperature for about $24 \mathrm{~h}$. Ammonium concentrations were determined manually, as described by Koroleff (1969, 1976). Freshly prepared Millipore MilliQ water served as blank solution; standardization was carried out with 2 series of 5 ammonium sulphate standards ranging between 0 and $1 \mu \mathrm{mol} \mathrm{N} \mathrm{l}^{-1}$ and between 0 and $3 \mu \mathrm{mol} \mathrm{N} \mathrm{l}^{-1}$.

Quantitative analysis of auto- and heterotrophic organisms was based on biovolume measurements and cell counts, using different microscopic techniques (Becquevort et al. 1991). The applied microscopic technique and the specific factors used for conversion of biovolumes into carbon units are reported in Table 1.

Biological activity. Total ammonium remineralization was determined with isotope $\left({ }^{15} \mathrm{~N}\right)$ dilution ex- periments, carried out on sea water sampled with $30 \mathrm{l}$ Niskin bottles. It is assumed that these samples, taken without any kind of screening, are representative of the microbial population in the water. The sea water samples were held in $2.75 \mathrm{~J}$ polycarbonate bottles (Nalgene), spiked with labelled ammonium $\left(97 \%{ }^{15} \mathrm{~N}\right.$ ) and incubated for $24 \mathrm{~h}$ at in situ temperature in the dark. Spike additions increased the ambient concentrations by $0.1 \mu \mathrm{mol} \mathrm{N}^{-1}$ Initial ammonium concentrations (immediately before and after spike addition) and final concentrations (at the end of the experiments) were measured. ${ }^{15} \mathrm{~N}$ abundances of ammonium at the start of the experiment were calculated by application of the isotope dilution law. From the differences between real and fitted values for the standard concentrations we conclude that the deviation for concentrations between 0 and $1 \mu \mathrm{mol} \mathrm{N} \mathrm{l}^{-1}$ amounted maximally to $2 \%$, and to $0.4 \%$ for concentrations exceeding $1 \mu \mathrm{mol} \mathrm{N}^{-1}$. This results in an estimated maximal coefficient of variation for the calculated ${ }^{15} \mathrm{~N}$ abundances of $29 \%$. Final ${ }^{15} \mathrm{~N}$ abundances of ammonium were determined by emission spectrometry, after isolation from the sea water matrix by an adapted diffusion method (Goeyens et al. unpubl.), and conversion into molecular nitrogen by the modified Dumas method (Fiedler \& Proksch 1975). The emission spectrometric readings, obtained with a Jasco Model NIA 1 N-15 Analyzer, were calibrated against certified standards (Goeyens et al. 1985) and against unenriched ammonium. Reproducibility tests for the emission spectrometric readings showed that the coefficients of variation never exceeded $2 \%$. Remineralization fluxes were calculated according to the modified linear differential equation model, introduced by Glibert et al. (1982b). Estimated errors for remineralization rates ranged between 5 and $30 \%$, with errors larger than $10 \%$ occurring when the samples showed high ammonium concentrations.

Ammonium remineralization rates through bacterial and protozoan activity were indirectly estimated from measurements of bacterial production and of protozoa

Table 1. Microscopic analysis methods and conversion factors of biovolume into carbon biomass

\begin{tabular}{|llcc|}
\hline Taxon & $\begin{array}{l}\text { Microscopic analysis } \\
\left(\mathrm{pg} C \mu \mathrm{m}^{-3}\right)\end{array}$ & Carbon/biovolume & Source \\
\hline $\begin{array}{l}\text { Phytoplankton } \\
\text { Diatoms } \\
\text { Flagellates }\end{array}$ & $\begin{array}{l}\text { Inverted light microscopy (Utermöhl 1958) } \\
\text { Epifluorescence staining (Porter \& Feig 1980) }\end{array}$ & 0.11 & Edler (1979) \\
$\begin{array}{l}\text { Protozooplankton } \\
>20 \mu \mathrm{m}\end{array}$ & Edler (1979) \\
$<20 \mu \mathrm{m}$ & Inverted light microscopy (Utermöhl 1958) & 0.08 & Sherr \& Sherr (1984) \\
Bacteria & Epifluorescence staining (Porter \& Feig 1980) & 0.11 & Edler (1979) \\
& Epifluorescence microscopy & Biovolume- & Simon \& Azam (1989) \\
\hline
\end{tabular}


grazing rates, conducted in parallel with the ${ }^{15} \mathrm{~N}$ experiments. Bacterial production rates were measured according to the thymidine incorporation method of Fuhrman \& Azam (1982). For several empirical calibrations with cell number increase in $0.2 \mu \mathrm{m}$ filtered sea water reinoculated with $2 \mu \mathrm{m}$ filtered water, as described by Rieman et al. (1987), a conversion factor of $1.25 \times 10^{9}$ cells $\mathrm{nmol}^{-1}$ thymidine incorporated was found. The carbon conversion was based on bacteria biovolume measurements using the conversion factors recommended by Simon \& Azam (1989) and the ammonium regeneration by bacteria was deduced from bacterial growth rates, assuming a growth yield of 0.3 and a $\mathrm{C} / \mathrm{N}(\mathrm{w} / \mathrm{w}$ ) ratio of 4 for the bacterial biomass as well as for its direct substrates. Protozoan grazing on algal cells and bacteria was estimated from cell counts and carbon biomasses, using a maximal hourly clearance rate of $10^{5}$ body volumes per protozoan as determined by Bjørnsen \& Kuparinen (1991). From these estimates ammonium regeneration was calculated using a growth yield of 0.3 and $\mathrm{C} / \mathrm{N}(\mathrm{w} / \mathrm{w})$ ratios of 4.5 and 5.6 for protozoa and phytoplankton respectively.

Nitrogen uptake rates were studied by means of isotope $\left({ }^{15} N\right)$ incorporation experiments. Sea water samples, spiked with labelled nitrate or ammonium, were incubated in $4 \mathrm{l}$ polycarbonate bottles for $24 \mathrm{~h}$ at $0^{\circ} \mathrm{C}$ with a $16 \mathrm{~h}: 8 \mathrm{~h}$ light: dark cycle. Incident radiation was $100 \mu \mathrm{E} \mathrm{m} \mathrm{m}^{-2} \mathrm{~s}^{-1}$. A detailed description of the methodology and resulting uptake rate data are given by Goeyens et al. (1991).

\section{RESULTS}

\section{General description of study area}

The physical structure of the studied area, as well as the sea ice conditions and the associated biological activities, leads to a distinction between 3 different subareas (Fig. 1): the permanently open ocean zone (POOZ), the marginal ice zone (MIZ) and the closed pack ice zone (CPIZ). The POOZ includes the Scotia Sea sector south of $57^{\circ} \mathrm{S}$ and the Scotia Front. Repeated samplings at the same geographical positions showed that this front developed from a narrow system, north of $58^{\circ} \mathrm{S}$, at the beginning of the cruise towards a more expanded one, situated ca $1 \frac{1}{2}$ further south, some 6 wk later (Cederlö et al. 1989).

The MIZ covered the area associated with ice retreat; it extended from $58^{\circ} 30^{\prime} \mathrm{S}$ to $61^{\circ} \mathrm{S}$ (Van Franeker 1989). At the beginning of the cruise the ice edge was situated at $58^{\circ} 30^{\prime} \mathrm{S}$ and 2 mo later had reached about $61^{\circ} \mathrm{S}$. The resulting mean receding rate for this part of the Weddell Sea amounts to about $5.5 \mathrm{~km} \mathrm{~d}^{-1}$. This zone was characterized by a low-salinity and lownitrate surface water lens (Goeyens et al. 1991) as well as by clearly increased biological activity at every trophic level: phytoplankton (Lancelot et al. 1991b), heterotrophic organisms (Billen \& Becquevort 1991, Lancelot et al. 1991a) and mesozooplankton (Schalk 1990). Its surface nitrate concentrations amounted to

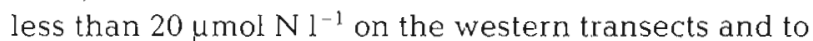
about $22 \mu \mathrm{mol} \mathrm{N}^{-1}$ on the eastern one: a depletion, as compared to winter nitrate concentrations, that is explained by phytoplankton assimilation rather than by dilution with melting ice (Goeyens et al. 1991). These decreases in surface nitrate coincided with strikingly increased ammonium pools, the maximal concentrations at the bottom of the euphotic layer exceeding $1.5 \mu \mathrm{mol} \mathrm{Nl}^{-1}$

Finally, the CPIZ, situated south of $60^{\circ} 30^{\prime} \mathrm{S}$, was characterized by very low microbial activity (Lancelot et al. 1991a). The measured nitrate concentrations remained very high (>27 $\mu \mathrm{mol} \mathrm{N}{ }^{-1}$ ) and no significant increases in ammonium stock were observed.

The experimental data on ammonium concentrations and remineralization rates and their distributions are discussed for each of the geographical zones.

\section{Ammonium distributions}

Vertical ammonium distributions generally showed concentrations increasing from the surface towards a subsurface maximum at a depth of 60 to $80 \mathrm{~m}$ and afterwards decreasing towards undectable levels $\left(<0.01 \mu \mathrm{mol} \mathrm{N} \mathrm{l}^{-1}\right)$ at some 150 to $200 \mathrm{~m}$. The maximal concentrations, however, as well as the depthintegrated amounts, differed remarkably within each zone.

The ammonium profiles for stations north of the Scotia Front generally exhibited a maximal concentration of ca $0.6 \mu \mathrm{mol} \mathrm{N}^{-1}$. MIZ stations were characterized by high subsurface maxima of $1.5 \mu \mathrm{mol} \mathrm{N} \mathrm{l^{-1 }}$ and more, occasionally reaching concentrations as high as $3 \mu \mathrm{mol} \mathrm{N} l^{-1}$. Finally, stations situated in the CPIZ of the Weddell Sea were characterized by much smaller maxima of 0.3 to $0.4 \mu \mathrm{mol} \mathrm{N}{ }^{-1}$ The observed variability in vertical ammonium distributions is illustrated by 4 contour plots, representing respectively Transects W1, W3, W4 and E (Fig. 2). A graphical representation of Transect $W 2$ is omitted since it comprises only a limited number of stations.

Depth-integrated amounts of ammonium for the upper $200 \mathrm{~m}$ of the water column, as well as average values for the 3 zones, are presented in Table 2 . The general trend was for highest stocks in the MIZ, lowest values in the CPIZ and intermediate values in the $\mathrm{POOZ}_{i}$ this is visualized in a contour diagram (Fig. 3) 

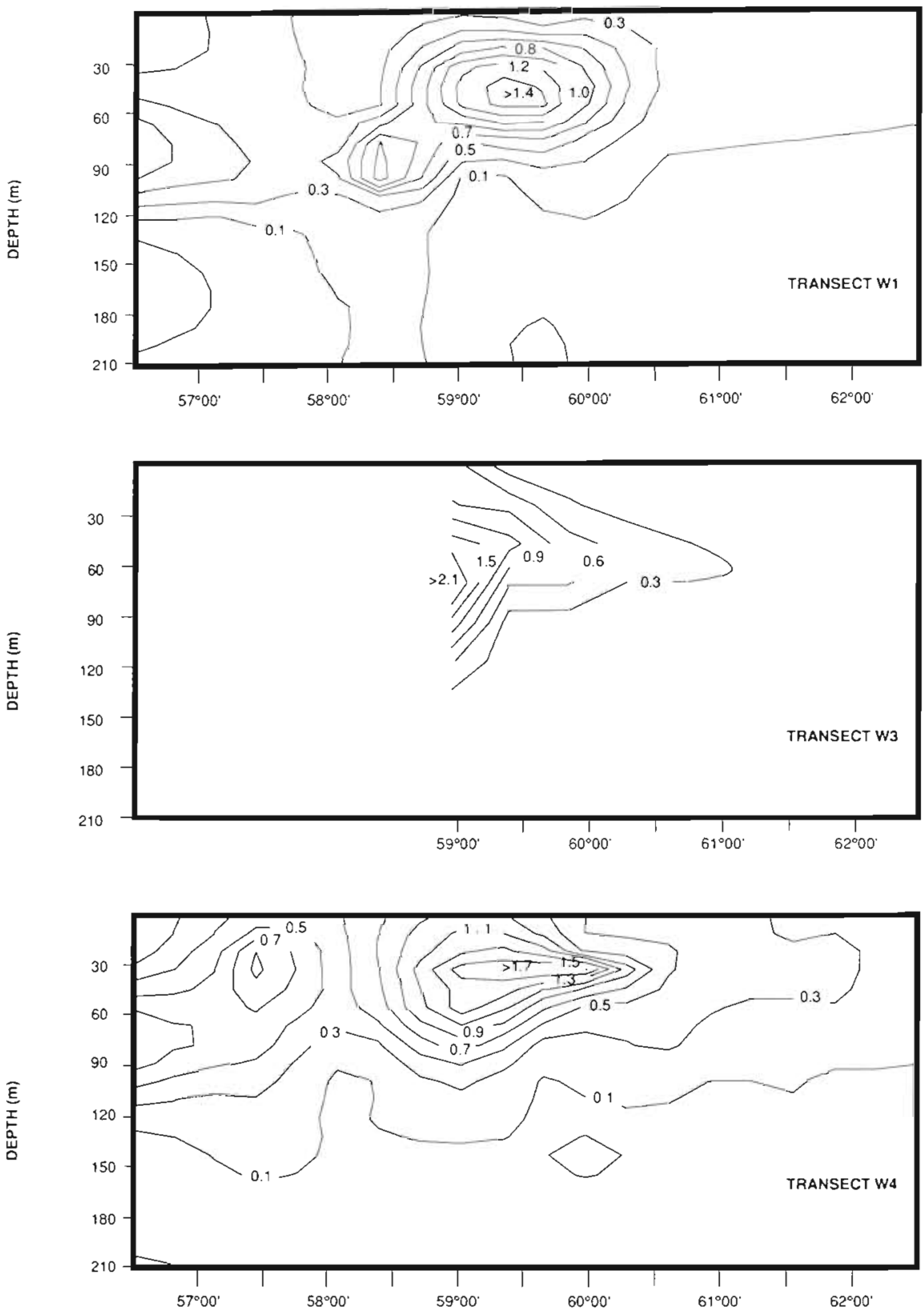

Fig. 2. Ammonium distributions in the upper $200 \mathrm{~m}$ of the water column along

Transects W1, W3, W4 and E

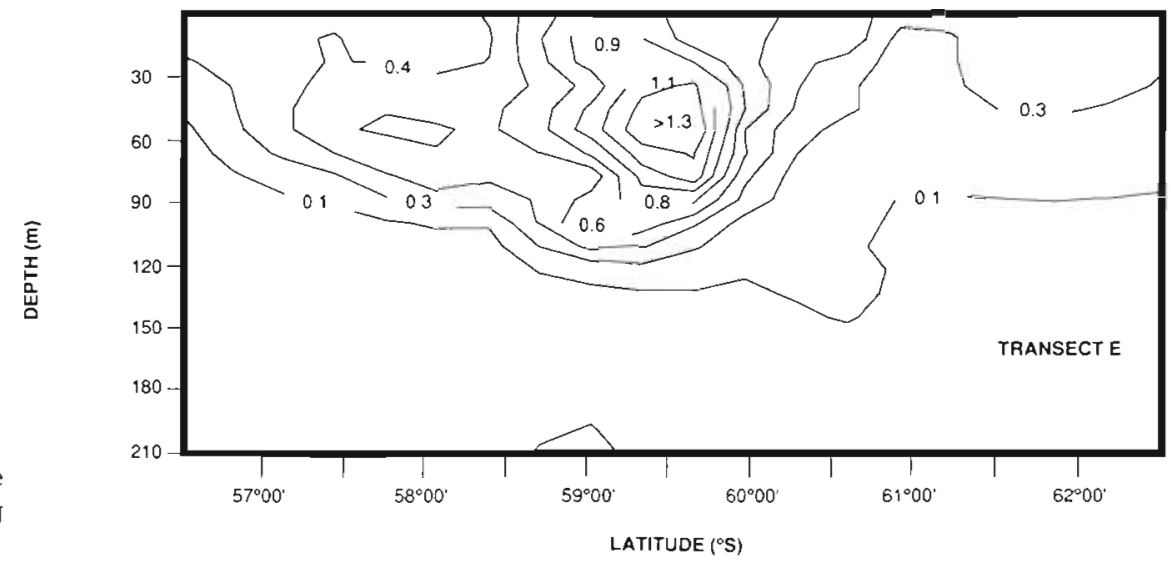


Table 2. Depth-integrated ammonium stocks (in mmol $\mathrm{N} \mathrm{m}^{-2}$ ), present in the upper $200 \mathrm{~m}$ of the water column

\begin{tabular}{|c|c|c|c|c|c|c|c|c|}
\hline \multicolumn{3}{|c|}{ POOZ } & \multicolumn{3}{|c|}{ MIZ } & \multicolumn{3}{|c|}{ CPIZ } \\
\hline Stn & Transect & $\mathrm{NH}_{4}$ stock & Stn & Transect & $\mathrm{NH}_{4}$ stock & Stn & Transect & $\mathrm{NH}_{4}$ stock \\
\hline 143 & W1 & 48 & 146 & W1 & 97 & 150 & W1 & 29 \\
\hline 144 & W1 & 60 & 147 & W1 & 75 & 151 & W1 & 27 \\
\hline 145 & W1 & 36 & 148 & W1 & 103 & 152 & W1 & 28 \\
\hline 159 & $w_{2}$ & 42,46 & 149 & W1 & 68 & 153 & W1 & 23 \\
\hline 160 & $\mathrm{E}$ & 27 & 157 & W/2 & 215 & 156 & W2 & 17 \\
\hline 161 & E & 42 & 158 & W2 & $88,104,106$ & 168 & $E$ & 18 \\
\hline 162 & $E$ & 54 & 163 & $E$ & 49 & 169 & $E$ & 27 \\
\hline 182 & W4 & 46 & 164 & $\mathrm{E}$ & 95 & 176 & W3 & 20 \\
\hline 183 & W4 & 81 & 165 & $E$ & 145 & 177 & W3 & 21 \\
\hline \multirow[t]{11}{*}{186} & W4 & 29 & 166 & $E$ & 57 & 178 & W3 & 22 \\
\hline & & & 167 & $E$ & 48 & 179 & w3 & 23 \\
\hline & & & 172 & W3 & 187 & 193 & W4 & 22 \\
\hline & & & 173 & w3 & 66 & 194 & W4 & 24 \\
\hline & & & 174 & W3 & 46 & & & \\
\hline & & & 175 & w3 & 27 & & & \\
\hline & & & 187 & W4 & 64 & & & \\
\hline & & & 188 & W4 & 124 & & & \\
\hline & & & 189 & W4 & 82 & & & \\
\hline & & & 190 & W4 & 59 & & & \\
\hline & & Mean: $46 \pm 15$ & & & Mean: $97 \pm 43$ & & & Mean: $23 \pm$ \\
\hline
\end{tabular}

For the MIZ a mean ammonium stock of $91 \pm 47 \mathrm{mmol}$ $\mathrm{N} \mathrm{m}^{-2}$ was observed; the highest and lowest measured stocks being respectively 215 and $27 \mathrm{mmol} \mathrm{N} \mathrm{m}^{-2}$ This extreme difference of an order of magnitude between the highest and lowest ammonium stocks indicates the highly variable biological activity in this zone. In the POOZ the average ammonium stock was $46 \pm 15 \mathrm{mmol}$ $\mathrm{N} \mathrm{m}^{-2}$, whereas in the CPIZ it amounts to $23 \pm 4 \mathrm{mmol}$ $\mathrm{N} \mathrm{m}{ }^{-2}$. Even though the data show a somewhat scat-

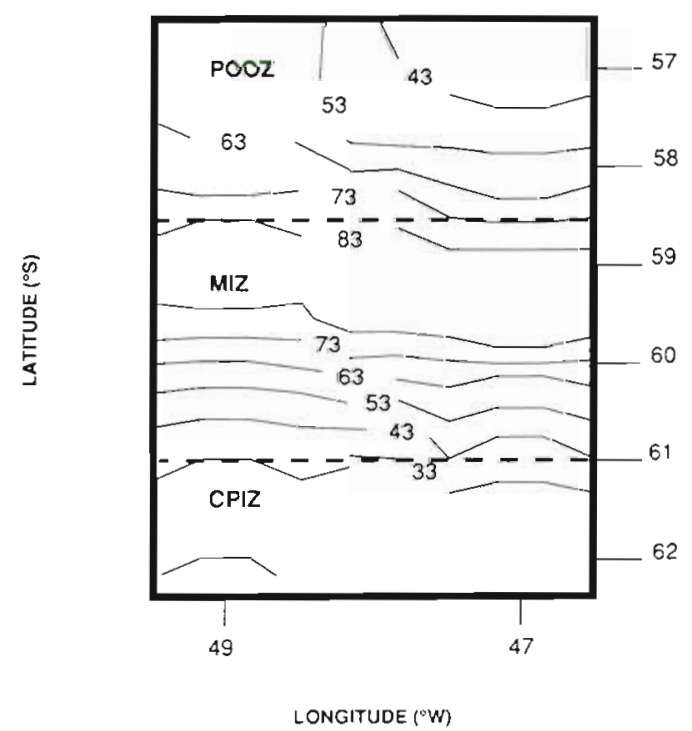

Fig. 3. Variability of the ammonium stocks, in $\mathrm{mmol} \mathrm{N} \mathrm{m}^{-2}$, in the study area tered pattern, the variability was much smaller in these zones, especially in the latter one.

\section{Ammonium fluxes}

Total ammonium remineralization. The results of the ${ }^{15} \mathrm{~N}$ dilution experiments are summarized in Table 3. For samples taken at different depths in the mixed layer, the remineralization rates show good reproducibility at all but one station (173, W3). In discussing ecological implications it is assumed that the remineralization process was homogeneous in the mixed layer, and averaged remineralization rates are considered.

The POOZ and the CPIZ were both characterized by very similar ammonium remineralization rates of about $2 \mathrm{nmol} \mathrm{N} \mathrm{l}^{-1} \mathrm{~h}^{-1}$. For 2 Scotia Sea stations 159 (W2) and 182 (W4), sampled at the beginning and at the end of the cruise, we observed an increasing trend in remineralization rate from 2.1 to $2.5 \mathrm{nmol} \mathrm{N}$ $\mathrm{I}^{-1} \mathrm{~h}^{-1}$ Correspondingly, a slight ammonium build-up was noted, reflected by a concentration increase from 0.34 to $0.65 \mu \mathrm{mol} \mathrm{N} \mathrm{I}^{-1}$. Measurements carried out at $3 \mathrm{CPIZ}$ stations at $61^{\circ} \mathrm{S}$ indicated a remineralization rate varying between 1.7 and $3.5 \mathrm{nmol} \mathrm{N} \mathrm{l}^{-1} \mathrm{~h}^{-1}$, with the lowest value of 1.7 found during Transect $W 2$, a higher value of 3.5 in the surface layer during Transect $W 3$ and again a lower value of 2.1 at the end of the cruise.

In contrast, the MIZ stations exhibited high ammonium remineralization rates, ranging from 5 to $16 \mathrm{nmol}$ 
Table 3. Remineralization rates

\begin{tabular}{|c|c|c|c|c|c|c|c|}
\hline Area & Stn & $\begin{array}{l}\text { Depth } \\
\text { (m) }\end{array}$ & $\begin{array}{l}\text { Ammonium } \\
\left(\mu \mathrm{mol} \mathrm{Ni}^{-1}\right)\end{array}$ & $\begin{array}{l}\text { Initial abundance } \\
\qquad\left(\%{ }^{15} \mathrm{~N}\right)\end{array}$ & $\begin{array}{c}\text { Final abundance } \\
\qquad|\%|, \infty)\end{array}$ & $\begin{array}{c}\text { Remin. rate } \\
\left(\text { nmol } \mathrm{N}^{-1} \mathrm{~h}^{-1}\right)\end{array}$ & $\begin{array}{c}\text { Mean rate } \\
\left(\text { nmol } \mathrm{N}^{-1} \mathrm{~h}^{-1}\right)\end{array}$ \\
\hline \multirow[t]{2}{*}{ POOZ } & 159 & 10 & 0.34 & 24 & 21 & 2.1 & \\
\hline & 182 & 20 & 0.65 & 49 & 44 & 2.5 & \\
\hline \multirow[t]{5}{*}{ MIZ } & $\begin{array}{l}157 \\
157\end{array}$ & $\begin{array}{l}10 \\
50\end{array}$ & $\begin{array}{l}1.53 \\
2.21\end{array}$ & $\begin{array}{l}4.8 \\
3.7\end{array}$ & $\begin{array}{l}3.6 \\
3.2\end{array}$ & $\begin{array}{l}18 \\
15\end{array}$ & 16 \\
\hline & $\begin{array}{l}172 \\
172\end{array}$ & $\begin{array}{l}20 \\
50\end{array}$ & $\begin{array}{l}0.72 \\
2.31\end{array}$ & $\begin{array}{l}11 \\
4.0\end{array}$ & $\begin{array}{l}9.6 \\
3.5\end{array}$ & $\begin{array}{l}5 \\
6\end{array}$ & 5 \\
\hline & $\begin{array}{l}173 \\
173\end{array}$ & $\begin{array}{l}20 \\
60\end{array}$ & $\begin{array}{l}0.08 \\
2.08\end{array}$ & $\begin{array}{l}42 \\
3.1\end{array}$ & $\begin{array}{l}34 \\
2.4\end{array}$ & $\begin{array}{l}1.7 \\
15\end{array}$ & 9 \\
\hline & $\begin{array}{l}174 \\
174\end{array}$ & $\begin{array}{l}20 \\
60\end{array}$ & $\begin{array}{l}0.14 \\
0.51\end{array}$ & $\begin{array}{r}38 \\
9\end{array}$ & $\begin{array}{l}13 \\
5.4\end{array}$ & $\begin{array}{l}9 \\
9\end{array}$ & 9 \\
\hline & 190 & 20 & 0.23 & 8.7 & 7.8 & 5.2 & \\
\hline \multirow[t]{3}{*}{ PICZ } & $\begin{array}{l}156 \\
156\end{array}$ & $\begin{array}{r}10 \\
120\end{array}$ & $\begin{array}{l}0.18 \\
0.05\end{array}$ & $\begin{array}{l}33 \\
90\end{array}$ & $\begin{array}{l}30 \\
88\end{array}$ & $\begin{array}{r}1.7 \\
<0.1\end{array}$ & \\
\hline & 176 & 20 & 0.06 & 58 & 34 & 3.5 & \\
\hline & 192 & 20 & 0.22 & 28 & 23 & 2.1 & \\
\hline
\end{tabular}

$\mathrm{N} \mathrm{l}^{-1} \mathrm{~h}^{-1}$. Almost every sample was characterized by enhanced ambient ammonium concentrations, some-

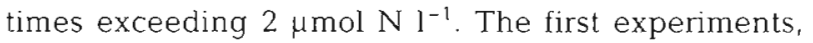
carried out at $59^{\circ} \mathrm{S}$ (Stn 157, W2), indicated especially high remineralization rates of respectively 18 and 15 nmol $\mathrm{N}^{-1} \mathrm{~h}^{-1}$ for samples taken at depths of 10 and $50 \mathrm{~m}$. Stns 172, 173 and 174, sampled $2 \mathrm{wk}$ later during Transect W3, and Stn 190, sampled 3 wk later during Transect W4, also exhibited high remineralization rates, although some decrease was seen. On average the W3 stations were characterized by remineraliza-

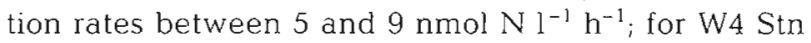

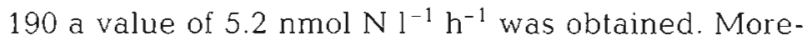
over, when comparing Stns 157 (W2) and 172 (W3), both located at $59^{\circ} \mathrm{S}, 49^{\circ} \mathrm{W}$, a considerable decrease in remineralization rate from 16 to $5 \mathrm{nmol} \mathrm{N} \mathrm{l}^{-1} \mathrm{~h}^{-1}$ occurred in a period of about 2 wk.

Ammonium regeneration by bacteria and protozoa. Ammonium regeneration rates by bacteria and protozoa (Table 4) were estimated from carbon biomass and metabolism measurements according to assumptions outlined in 'Material and methods'. Comparison of ammonium remineralization by these 2 microheterotrophic groups with total ammonium remineralization measured by ${ }^{15} \mathrm{~N}$ dilution experiments (Table 4) shows good agreement between the approaches. This indicates that the ${ }^{15} \mathrm{~N}$ experiments in general give a good estimate of the regeneration process, mediated by pico-, nano- and microplanktonic organisms. At one station (174, W3), however, a severe discrepancy between the methods possibly suggests the presence of mesozooplanktonic organisms in the ${ }^{15} \mathrm{~N}$ large volume sampling bottles.
While on average of equal importance, the relative and quantitative contribution of bacteria and protozoa in ammonium regeneration varied greatly from one station to another (Table 4). The bacterial remineralization rate varied between 0.6 and $17.8 \mathrm{nmol} \mathrm{N}$ $\mathrm{l}^{-1} \mathrm{~h}^{-1}$, contributing 11 to $99 \%$ to the total regeneration process by microheterotrophs. As a general trend the highest values ( $>1 \mathrm{nmol} \mathrm{N} \mathrm{l}^{-1} \mathrm{~h}^{-1}$ ) were measured in open areas, whereas the lowest values $(<1 \mathrm{nmol} N$ $\mathrm{l}^{-1} \mathrm{~h}^{-1}$ ) were characteristic for ice-covered areas. For one station (157, W2) bacterial activity was exceptionally high (17.8 nmol $\left.\mathrm{N}^{-1} \mathrm{~h}^{-1}\right)$ but in perfect agreement with the ${ }^{15} \mathrm{~N}$ data. This enhanced bacterial activity and almost negligible protozoan grazing can be explained by the recent passage of a krill swarm in this area, producing great amounts of dissolved organic matter through sloppy feeding on a localized plankton bloom (Bergstrom et al. 1989). Protozoan regeneration

Table 4. Comparison between $\mathrm{NH}_{4}$ remineralization rates (in nmol $\mathrm{N} \mathrm{l}^{-1} \mathrm{~h}^{-1}$ ) obtained from ${ }^{15} \mathrm{~N}$ incubation experiments and calculated from microbial biomass and activity measurements

\begin{tabular}{|ccccc|}
\hline Stn & Bemineralization rate & \\
& Bacteria & Protozoa & Total & $\begin{array}{c}15 \mathrm{~N} \text { isotope } \\
\text { dilution }\end{array}$ \\
\hline 156 & 0.9 & 0.3 & 1.2 & 1.7 \\
157 & 17.8 & 0.1 & 17.9 & 18 \\
172 & 1 & 3.1 & 4.1 & 5 \\
173 & 1 & 8 & 9 & 9 \\
174 & 1.2 & 0.7 & 1.9 & 9 \\
176 & 0.6 & 1.6 & 2.2 & 3.5 \\
190 & 2.5 & 1.3 & 3.8 & 5.2 \\
\hline
\end{tabular}


rates on the other hand ranged between 0.1 and 8 nmol N I-1 $\mathrm{h}^{-1}$, contributing from 1 to $89 \%$ to the microheterotrophic regeneration process. It is, however, hard to deduce a clear trend from the analysis of the spatio-temporal variability in protozoan regeneration rates reported in Table 4

\section{DISCUSSION}

\section{Ammonium distributions}

The majority of the inorganic nitrogen in the world's oceans is in the thermodynamically stable form of nitrate; labile compounds such as ammonium are usually present in comparatively low concentrations. Generally, they amount to less than $0.5 \mu \mathrm{mol} \mathrm{N}$ $1^{-1}$ in oceanic surface water and to less than $0.1 \mu \mathrm{mol}$ $\mathrm{N} \mathrm{I}^{-1}$ in deeper water. Vertical profiles mostly show a discrete maximum near the bottom of the euphotic zone (Sharp 1983). Vertical ammonium distributions in the Southern Ocean fit in with this general description, but during the growth season much higher maximal concentrations have been measured in the subsurface layer. A very high concentration of 4.5 $\mu \mathrm{mol} \mathrm{N} l^{-1}$ is given for the Bransfield Strait (Koike et al. 1986). Similarly, we have recently (RV 'Aurora Australis', Marine Science Voyage 6, January to March 1991) measured concentrations exceeding 4 $\mu \mathrm{mol} \mathrm{N}{ }^{-1}$ in the Prydz Bay area (unpubl.). Concen-

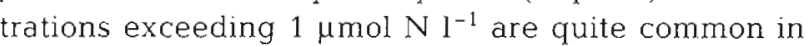
the Ross Sea (El Sayed et al. 1983, Biggs et al. 1985), as well as in the Scotia-Weddell area (Rönner et al. 1983), and in the Indian Ocean sector (Slawyk 1979 Verlencar et al. 1990). On the EPOS LEG 2 cruise in the Scotia and Weddell Sea sector during spring 1988 highest concentrations were found in the MIZ (Figs. 2 $\& 3)_{i}$ these maximal values ranged between 1.6 and

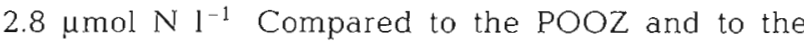
CPIZ the maximal concentrations in the MIZ were about 4 to 10 times higher. During the cruise period, the POOZ was in general characterized by maximum

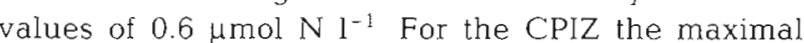

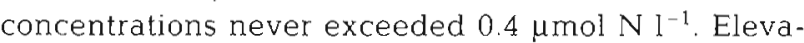
ted ammonium concentrations in the subsurface layer resulted in high integrated stocks and high depthaveraged concentrations (Table 5). The latter values for the MIZ amounted respectively to $0.43,0.64,0.41$, 0.41 and $0.39 \mu \mathrm{mol} \mathrm{N} \mathrm{N}^{-1}$ along Transects $\mathrm{W} 1, \mathrm{~W} 2$, W3, W4 and E. In the other 2 sectors they were significantly lower For the POOZ values of $0.23,0.26$ and $0.21 \mu \mathrm{mol} \mathrm{N} \mathrm{^{-1 }}$ were respectively found at Transects W1, W4 and E, whereas in the CPIZ 0.13, 0.19, 0.11, 0.12 and $0.11 \mu \mathrm{mol} \mathrm{N} \mathrm{I}^{-1}$ were measured for Transects W1, W2, W3, W4 and E.

\section{Remineralization process}

In the literature enhanced biomasses at different trophic levels are reported for the MIZ (Garrison et al. 1986, Smith \& Nelson 1986, Ross \& Quetin 1986). Similarly, markedly higher amounts for organisms of different trophic levels were observed in the MIZ during this study (Schalk 1990, Becquevort et al. 1991, Billen \& Becquevort 1991, Jacques \& Panouse 1991). Summarized information on algal and microheterotrophic biomasses is given in Table 5 . In the euphotic zone of Antarctic waters, extensive grazing on pico- and nanoplankton by nano- and microheterotrophs can take place. Several authors (Smetacek et al. 1990, Lancelot et al. 1991a) confirm that this heterotrophic microbial process is to be considered an important fraction of the MIZ production. Distribution data for microheterotrophs $(<200 \mu \mathrm{m})$, presented by Becquevort et al (1991), show highest biomasses occurred consistently in the MIZ (Table 5). In comparison with the POOZ and the CPIZ, microheterotrophic biomasses in the MIZ were about one order of magnitude higher, Nano- and picoplanktonic organisms were generally the most abundant fraction of this heterotrophic community; in the MIZ their biomasses represented between 70 and $90 \%$ of the microheterotrophs. Moreover, these authors showed that phytoplankton development was accompanied by the almost simultaneous development of a protozoan community dominated by dinoflagellates. The bacterial activity was, however, slightly delayed.

The rates of remineralization by micrograzers and bacteria, obtained from ${ }^{15} \mathrm{~N}$ dilution experiments and estimated from biomasses and carbon metabolism (Tables 2 \& 4), confirm the importance of these microorganisms as ammonium producers. The experimental results for the POOZ as well as for the CPIZ indicate mean remineralization rates of $2 \mathrm{nmol}$ $\mathrm{N}^{-1} \mathrm{~h}^{-1}$ and during the period of the cruise these rates never showed a marked increase. A completely different time-course was demonstrated in the MIZ, where remineralization rates were a factor of 2 to 8 higher and decreased slightly from north to south The data for Transect $W 3$ reveal that the remineralization process was predominantly mediated by protozoan activity and, especially at the lower latitudes (Stns $172 \& 173$ ), a preponderance of protozoan regeneration was observed. Bacterial activity remained almost constantly low in the entire MIZ during Transect $W 3$ and this differs fundamentally from Stn 157 (W2), characterized by the krill event and a very high bacterial remineralization. It would appear that a krill swarm, grazing on autotrophic as well as on heterotrophic prey organisms, generates huge amounts of organic substrates and thereby 
Table 5. Depth-averaged values for ammonium stocks, autotrophic and heterotrophic biomasses in the studied area

\begin{tabular}{|c|c|c|c|c|c|}
\hline Stn & Zone & $\begin{array}{l}\text { Ammonium } \\
\left.(\mu \mathrm{mol}]^{-1}\right)\end{array}$ & $\begin{array}{c}\text { Chlorophyll } a^{\prime \prime} \\
\left(\mu \mathrm{g} \mathrm{i}^{-1}\right)\end{array}$ & $\begin{array}{c}\text { Microheterotrophs }{ }^{b} \\
\left(\mu \mathrm{C} \mathrm{Cl}^{-1}\right)\end{array}$ & $\begin{array}{l}\text { Bacteria } \\
\left(\mu \mathrm{gCl} \mathrm{I}^{-1}\right)\end{array}$ \\
\hline$W 1,143$ & POOZ & 0.24 & 0.15 & & 2.2 \\
\hline 144 & POOZ & 0.30 & 0.11 & & \\
\hline 145 & POOZ & 0.18 & 0.33 & & 13.6 \\
\hline 146 & MIZ & 0.49 & 1.76 & & 8.1 \\
\hline 147 & MIZ & 0.38 & 0.84 & 13.1 & \\
\hline 148 & MIZ & 0.52 & 0.44 & & 6.2 \\
\hline 149 & MIZ & 0.34 & 0.27 & & \\
\hline 150 & CPIZ & 0.13 & 0.14 & & 1.4 \\
\hline 151 & CPIZ & 0.14 & 0.15 & 3.0 & 1.2 \\
\hline 152 & CPIZ & 0.14 & 0.12 & & 2.8 \\
\hline 153 & CPIZ & 0.13 & 0.14 & & 2.5 \\
\hline W3, 172 & MlZ & 0.94 & 0.27 & 26.3 & 4.4 \\
\hline 173 & MIZ & 0.33 & 0.36 & 30.2 & 5.0 \\
\hline 174 & MIZ & 0.23 & 0.27 & 12.6 & 5.2 \\
\hline 175 & MIZ & 0.14 & 0.23 & 8.4 & 3.3 \\
\hline 176 & CPIZ & 0.10 & 0.26 & 10.31 & 3.8 \\
\hline 177 & CPIZ & 0.11 & 0.19 & 4.7 & 4.3 \\
\hline 178 & CPIZ & 0.11 & 0.18 & 6.3 & 4.0 \\
\hline 179 & CPIZ & 0.12 & 0.12 & 2.2 & 1.6 \\
\hline W4, 182 & $\mathrm{POOZ}$ & 0.23 & 0.24 & & 5.7 \\
\hline 183 & POOZ & 0.41 & 0.16 & & 10.8 \\
\hline 186 & $\mathrm{POOZ}$ & 0.15 & 0.15 & & 7.4 \\
\hline 187 & MIZ & 0.23 & 0.32 & & 3.8 \\
\hline 188 & MIZ & 0.62 & 0.15 & & 8.9 \\
\hline 189 & MIZ & 0.41 & 0.17 & & 18.3 \\
\hline 190 & MIZ & 0.30 & 0.40 & 7.2 & 8.2 \\
\hline 191 & CPIZ & 0.22 & 0.28 & & 6.2 \\
\hline 192 & CPIZ & 0.14 & 0.22 & & 5.9 \\
\hline 193 & CPIZ & 0.11 & 0.19 & 1.97 & 3.9 \\
\hline 194 & CPIZ & 0.12 & 0.19 & & \\
\hline$E, 160$ & $\mathrm{POOZ}$ & 0.14 & 0.09 & 6.03 & 10.4 \\
\hline 161 & POOZ & 0.21 & 0.09 & 6.6 & 1.9 \\
\hline 162 & POOZ & 0.27 & 0.10 & & 5.4 \\
\hline 163 & MIZ & 0.25 & 0.11 & 7.7 & 3.1 \\
\hline 164 & MIZ & 0.48 & 0.27 & 4.1 & 4.9 \\
\hline 165 & MIZ & 0.73 & 0.22 & 1.6 & 2.5 \\
\hline 166 & MIZ & 0.29 & 0.23 & 2.5 & 5.4 \\
\hline 167 & MIZ & 0.24 & 0.26 & 6.2 & 3.0 \\
\hline 168 & CPIZ & 0.09 & 0.26 & 3.6 & 3.0 \\
\hline 169 & CPIZ & 0.14 & 0.19 & 4.2 & 1.6 \\
\hline
\end{tabular}

triggers the bacterial activity.

When considering mesozooplankton, Schalk (1990) stated that the lowest biomasses are found under the pack ice, whereas considerably higher values occur close to and in the MIZ. Micronekton biomass was shown to be relatively high north of the MIZ. Reported maximal zooplankton biomasses were $30 \mathrm{~g}$ (wet wt) $\mathrm{m}^{-2}$ in the MIZ and $24 \mathrm{~g}$ (wet wt) $\mathrm{m}^{-2}$ at the ice-covered stations. The krill biomass measured during the same expedition varied between 0.2 and $45 \mathrm{~g}$ (wet wt) $\mathrm{m}^{-2}$; with one station (157, W2) being characterized by an exceptionnally dense krill swarm of $400 \mathrm{~g}$ (wet wt) $\mathrm{m}^{-2}$. When taking into account the maximal zooplankton biomass of $30 \mathrm{~g}$ (wet wt) $\mathrm{m}^{-2}$, caught in a vertical haul from a depth of $400 \mathrm{~m}$, it is calculated that the zooplanktonic contribution to the ammonium input did not exceed $0.12 \mathrm{nmol} \mathrm{N} \mathrm{l}^{-1} \mathrm{~h}^{-1}$. This production rate was obtained by using the ammonium excretion rate for mixed zooplankton of $1.6 \mu$ mol $\mathrm{N}$ (g wet $\mathrm{wt})^{-1} \mathrm{~h}^{-1}$, given by Biggs (1982). As the biomass caught at $59^{\circ} \mathrm{S}$ during Transect $W 1$ was the highest for the area studied, the corresponding excretion rate is considered to be an absolutely maximal estimate. Calculated rates of ammonium excretion by krill, obtained from observed krill stocks and from the excretion formula described by Johnson et al. (1984), range generally from 0.001 to $0.08 \mathrm{nmol} \mathrm{N} \mathrm{l}^{-1} \mathrm{~h}^{-1}$. At the krill-rich station (157, W2) about $0.45 \mathrm{nmol} \mathrm{N} \mathrm{l}^{-1} \mathrm{~h}^{-1}$ was pro- 
duced by the swarm. This value is given for completeness only. As none of the other stations exhibited dense swarms like this, the ammonium excretion by krill is estimated to amount maximally to $0.08 \mathrm{nmol} \mathrm{N} \mathrm{l}^{-1} \mathrm{~h}^{-1}$ for the studied area. Both estimates lead to ammonium production rates due to mesozooplankton activity of less than $0.2 \mathrm{nmol} \mathrm{N} \mathrm{I}^{-1} \mathrm{~h}^{-1}$. When compared to the remineralization rates for bacterial and microzooplankton activities (Tables $3 \& 4$ ), the mesozooplankton clearly contributes only in a minor degree to the ammonium regeneration process, a conclusion that is in good agreement with previous results (Biggs 1982, Biggs et al. 1985).

\section{Implications for new-to-regenerated production ratio}

In the studied area ammonium regeneration processes were remarkably important in the MIZ, with the adjacent POOZ and CPIZ showing significantly less ammonium production in the mixed layer during the cruise period (Fig. 4A). This resulted in different ammonium build-up and different availability ratios of nitrogenous nutrients in the 3 zones (Figs. 4B, C). Average ammonium pools for 5 consecutive transects were 46, 91 and $22 \mathrm{mmol} \mathrm{N} \mathrm{m}^{-2}$ in the POOZ, MIZ and CPIZ respectively, and the corresponding nitrateto-ammonium ratios in the euphotic layer were 98,26 and 130

Previously it has been shown by Smith \& Nelson (1990) that Antarctic phytoplankton has the ability to increase its rate of ammonium uptake when availabilty is increased. On the other hand, it is known for temperate regions (Wheeler \& Kokkinnakis 1990), and also for Antarctic systems (Smith \& Nelson 1990, Sörensson unpubl.), that nitrate uptake is reduced at elevated ammonium levels. Both these considerations explain well the noticed shift from predominant new production towards regenerated production in the MIZ during the period of this study (Fig. 4D), but also the comparatively slight decrease in the f-ratio in both the POOZ and the CPIZ, as described by Goeyens et al. (1991). The f-ratios obtained for repeated uptake measurements at $59^{\circ} \mathrm{S}$ and at $59^{\circ} 30^{\prime} \mathrm{S}$ (in the MIZ) decreased significantly from 0.8 at the beginning of the cruise to 0.30 at the end. On the other hand, much less variation was observed for the POOZ and for the CPIZ. The former showed a slightly decreasing f-ratio (0.51 during Transect $W 1$ and 0.47 during Transects $W 2$ and E), whereas the latter showed similar f-ratios of 0.62 and 0.61 during Transects $W 1$ and $W 2$. These observations are evidence that the importance of ammonium generation by microbial heterotrophic activity increased as the season progressed. Especially in the MIZ, however, the transition towards ammonium-based production
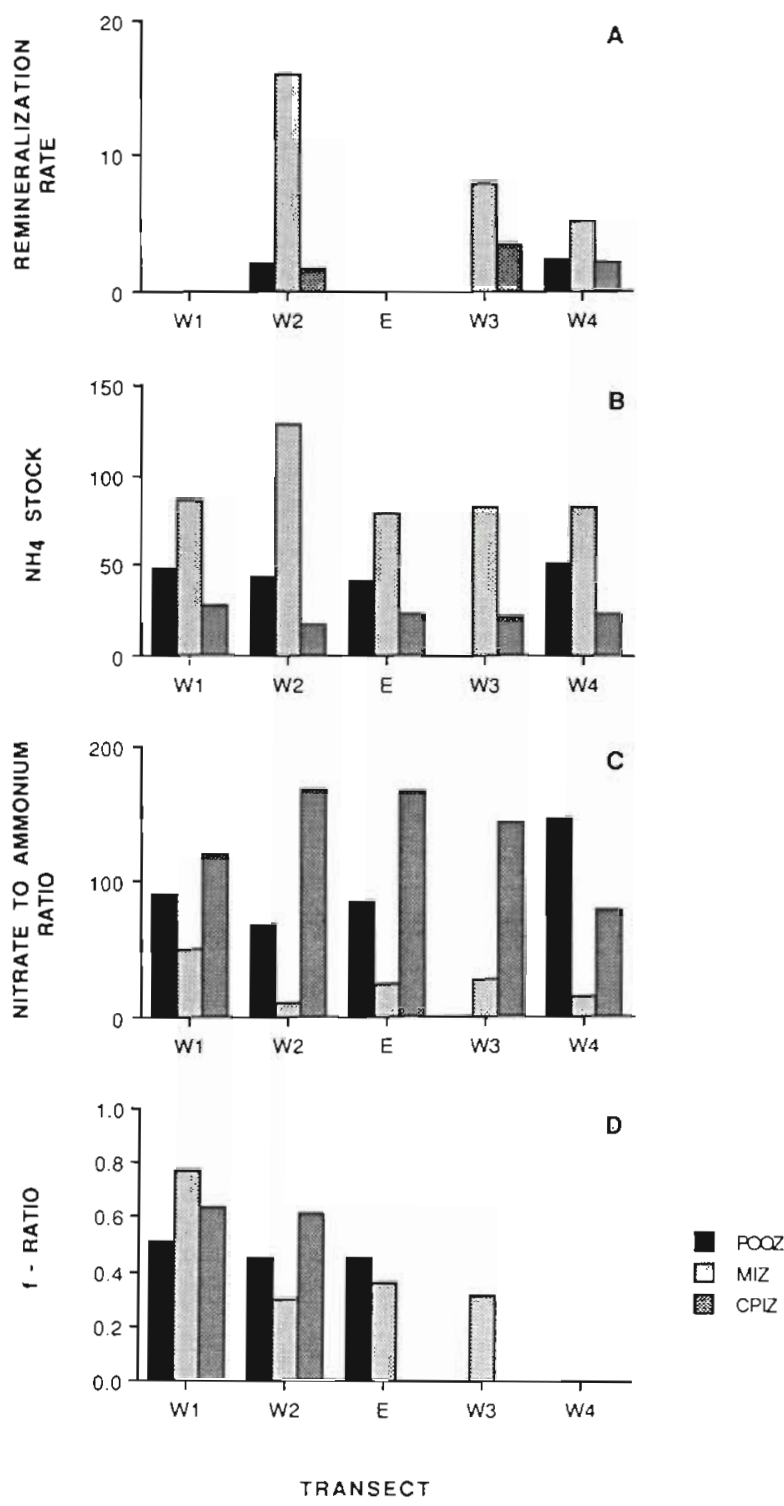

Fig. 4. Seasonal time-course of (A) ammonium regeneration rates (nmol $\mathrm{N} \mathrm{l}^{-1}$ ), (B) ammonium stocks (mmol $\mathrm{N} \mathrm{m}^{-2}$ ), (C) availability of nitrogenous nutrients as nitrate-to-ammonium ratios, and (D) f-ratios in the 3 subareas

was more drastic even though nitrate was never negligible for phytoplankton nutrition. For this ecosystem the original idea of regenerating systems, consisting of autotrophs assimilating recycled nutrients produced by heterotrophs after the nitrate pool was exhausted, does not hold.

Acknowledgements. Data presented here were collected during the European 'Polarstern' Study (EPOS); the research forms part of the 'Belgian Scientific Research Programme on Antarctica - phase two' (Prime Minister's Services - Science Policy Office). Financial support from the European Science Foundation and the Alfred Wegener Institute for Polar and 
Marine Research, from the Belgian Science Policy Office and from the French Ministry for Education and CNRS, are very gratefully acknowledged. We take the opportunity to thank the captain and the crew members of RV 'Polarstern' for the magnificent treatment on board and for their tireless, able assistance.

\section{LITERATURE CITED}

Becquevort, S., Mathot, S., Lancelot C. (1991). Structure of the microbial network in the MIZ of the Weddell Sea through size distribution analysis. Polar Biol. (in press)

Bergstrom, B., Hempel, G., Hempel, I., Marschall, H. P., North, A., Siegel, V., Stromberg, J. O. (1989). Antarctic krill (Euphausia superba). In: Hempel, I. (ed.) Reports on Polar Research 62, Alfred Wegener Institute, Bremerhaven, p. 149-156

Biggs, D.C. (1982). Zooplankton excretion and ammonium cycling in near surface waters of the Southern Ocean. I. Ross Sea, austral summer, 1977-1978. Polar Biol. 1: 55-67

Biggs, D. C., Amos, A. F., Holm-Hansen, O. (1985). Oceanic studies of epi-pelagic ammonium distributions: the Ross Sea ammonium flux experiment. In: Siegfried, W. R., Condy, P. R., Laws, R. M. (eds.) Antarctic nutrient cycles and food webs. Springer-Verlag, Berlin, p 93-103

Billen, G., Becquevort, S. (1991). Phytoplankton-bacteria relationship in the Antarctic marine ecosystem. Polar Res. 10: in press

Bjørnsen, P. K., Kuparinen, J. (1991). Growth and herbivory by heterotrophic dinoflagellates in the Southern Ocean, studied by microcosm experiments. Mar. Biol. 109: $397-405$

Cederlof, U., Ober, S., Schmidt, R., Svansson, A., Veth, C. (1989). Hydrography. In: Hempel, I., Schalk, P. H., Smetacek, V. (eds.) Reports on Polar Research 65, Alfred Wegener Institute, Bremerhaven, p. 14-24

Collos, Y., Slawyk, G. (1986). ${ }^{13} \mathrm{C}$ and ${ }^{15} \mathrm{~N}$ uptake by marine phytoplankton - uptake ratios and the contribution of nitrate to the productivity of Antarctic waters (Indian Ocean sector). Deep Sea Res. 33: 1039-1051

Dugdale, R. C., Goering, J. J. (1967). Uptake of new and regenerated forms of nitrogen in primary productivity. Limnol. Oceanogr. 12: 196-206

Edler, L. (1979). Recommendations for marine biological studies in the Baltic Sea - phytoplankton and chlorophyll. Baltic Mar. Biol. 5: 1-38

El-Sayed, S. Z., Biggs, D. C., Holm-Hansen, O. (1983). Phytoplankton standing crop, primary productivity, and nearsurface nitrogenous nutrient fields in the Ross Sea, Antarctica. Deep Sea Res. 30:871-886

EPOS LEG 2 (1989). EPOS LEG 2 data report hydrography, Part 1, Netherlands Institute for Sea Research, Texel

Eppley, R. W., Peterson, B. J. (1979). Particulate organic flux and planktonic new production in the deep ocean. Nature, Lond. 282: $677-680$

Fiedler, R., Proksch, G. (1975). The determination of nitrogen15 by emission and mass spectrometry in biochemical analysis: a review. Analyt. Chim. Acta 78: 1-62

Fuhrman, J. A., Azam, F. (1982). Thymidine incorporation as a measure of heterotrophic bacterioplankton evaluation in marine surface waters: evaluation and field results. Mar. Biol. 66: 106-120

Garrison, D. L., Sullivan, C. W., Ackley, S. F. (1986). Sea ice microbial communities in Antarctica. Bioscience 36 : 243-250

Glibert, P. M., Biggs, D. C., McCarthy, J. J. (1982a). Utilization of ammonium and nitrate during austral summer in the Scotia Sea. Deep Sea Res. 29: 837-850

Glibert, P. M., Lipschultz, F., McCarthy, J. J., Altabet, M A. (1982b). Isotope dilution methods of uptake and remineralization of ammonium by marine plankton. Limnol. Oceanogr. 27: 639-650

Goeyens, L., Sörensson, F., Tréguer, P., Morvan, J., Panouse, M., Deharrs, F. (1991). Spatiotemporal variability of inorganic nitrogen stocks and assimilatory fluxes in the ScotiaWeddell Confluence area. Mar. Ecol. Prog. Ser 77: 7-19

Goeyens, L. G., Stichelbaut, L. W., Post, E. J., Baeyens, W. F. (1985). Preparation method for solid samples with low nitrogen content for spectrometric nitrogen-15 analysis. Analyst 110: 135-139

Hewes, C. D., Holm-Hansen, O., Sakshaug, E. (1985). Alternate carbon pathways at lower trophic levels in the Antarctic food web. In: Siegfried, W. R., Condy, P. R., Laws, R. $M$. (eds.) Antarctic nutrient cycles and food webs. Springer-Verlag, Berlin, p 277-283

Jacques, G., Panouse, M. (1991). Biomass and composition of size fractionated phytoplankton in the Weddell-Scotia Confluence area. Polar Biol. 11: 315-328

Johnson, M. A., Macaulay, M. C., Biggs, D. C. (1984). Respiration and excretion within a mass aggregation of Euphausia superba: implications for krill distribution. J. Crust. Biol. 4: 174-184

Koike, I., Holm-Hansen, O., Biggs, D. C. (1986). Inorganic nitrogen metabolism by Antarctic phytoplankton with special reference to nitrogen cycling. Mar. Ecol. Prog. Ser. 30: $105-116$

Koroleff, F. (1969). Direct determination of ammonia in natural waters as indophenol blue. Comm. Meet. int. Counc Explor. Sea, C. M.-ICES/C: 19-22

Koroleff, F. (1976). Determination of ammonia. In: Grasshoff K. (ed.) Methods of seawater analysis. Verlag Chemie, Weinheim, p. 126-133

Lancelot, C., Billen, G., Becquevort, S., Mathot, S., Veth, C. (1991a). Modelling carbon cycling through phytoplankton and microbes in the Scotia-Weddell Sea area during ice retreat. Mar. Chem. 35: 305-324

Lancelot, C., Veth, C., Mathot, S. (1991b). Modelling ice edge phytoplankton bloom in the Scotia-Weddell Sea sector of the Southern Ocean during spring 1988. J. mar. Syst. 2 $333-346$

Le Jehan. S., Tréguer, P. (1983). Uptake and regeneration $\Delta \mathrm{Si} / \Delta \mathrm{N} / \Delta \mathrm{P}$ ratios in the Indian sector of the Southern Ocean. Orıginality of the biological cycle of silicon. Polar Biol. 2: $127-136$

McCarthy, J. J., Taylor, W. R., Taft, J. L. (1977). Nitrogenous nutrition of the plankton in the Chesapeake Bay. 1. Nutrient availability and phytoplankton preferences. Limnol. Oceanogr. 22: 996-1011

Nelson, D. M., Smith, W. O. Jr. (1986). Phytoplankton bloom dynamics of the western Ross Sea ice edge - II. Mesoscale cycling of nitrogen and silicon. Deep Sea Res. 33 1389-1412

Olson, R. J. (1980). Nitrate and ammonium uptake in Antarctic waters. Limnol. Oceanogr. 25: 1064-1074

Porter, K. G., Feig, Y S. (1980). The use of DAPI for identifying and counting aquatic microflora. Limnol. Oceanogr 25: $943-948$

Probyn, T. A., Painting, S. J. (1985). Nitrogen uptake by sizefractionated phytoplankton populations in Antarctic surface waters. Limnol. Oceanogr. 30: 1327-1332

Rieman, B., Björnsen, P. K., Newell, S. Y., Fallon, R. D. (1987). Calculation of bacterioplankton production from measurements of ${ }^{3} \mathrm{H}$-thymidine incorporation. Limnol. Oceanogr. 
32: $471-476$

Rönner, U, Sörensson, F., Holm-Hansen, O. (1983). Nitrogen assimilation by phytoplankton in the Scotia Sea. Polar Biol. 2: $137-147$

Ross, R. M., Quetin, L. B. (1986). How productive are Antarctic krill? Bioscience 36: 264-269

Schalk, P. H. (1990). Biological activity in the Antarctic zooplankton community. Polar Biol. 10: 405-411

Sharp, J. H. (1983). The distributions of inorganic nitrogen and dissolved and particulate organic nitrogen in the sea In: Carpenter, E. J., Capone, D. G. (eds.) Nitrogen in the marine environment. Academic Press, New York, p 1-35

Sherr, B. F., Sherr, E. B. (1984). Role of heterotrophic protozoa in carbon and energy flow in aquatic ecosystems. In: Klug. M. J., Reddy, C. A. (eds.) Current perspectives in microbial ecology. American Society for Microbiology, Washington D.C., p 412-423

Simon, M, Azam, F. (1989). Protein content and protein synthesis rates of planktonic marine bacteria. Mar. Ecol. Prog Ser. $51.201-213$

Slawyk, G. (1979). ${ }^{13} \mathrm{C}$ and ${ }^{15} \mathrm{~N}$ uptake by phytoplankton in the Antarctic upwelling area: results from the Antiprod cruise in the Indian Ocean sector. Aust. J. mar. Freshwat. Res. 30: $431-438$

Smetacek, V., Scharek, R., Nöthig, E.-M. (1990). Seasonal and regional variation in the pelagial and its relationship to the life history cycle of krill. In: Kerry, K., R., Hempel, G. (eds.)

This article was submitted to the editor
Antarctic ecosystems, ecological change and conservation. Springer-Verlag, Berlin, p 103-114

Smith, W. O. Jr, Harrison, W. G. (1991). New production in polar regions: the role of environmental controls. Deep Sea Res. 38: 1463-1479

Smith, W. O. Jr, Nelson, D. M. (1986). Importance of ice edge phytoplankton production in the Southern Ocean. Bioscience 36: $251-257$

Smith, W. O. Jr, Nelson, D. M. (1990). Phytoplankton growth and new production in the Weddell Sea MIZ in the austral spring and autumn. Limnol. Oceanogr. 35: 809-821

Tréguer, P., Le Corre, P. (1975). Manuel d'analyses automatiques des sels nutritifs par AutoAnalyser II Technicon. Université de Bretagne Occidentale, Brest

Utermöhl, H. (1958). Zur Vervollkommnung der quantativen Phytoplankton-Methodik. Mitt. int. Verein theor. angew. Limnol. 9: 1-38

Van Franeker, J. A. (1989). Sea ice conditions. In: Hempel, I., Schalk, P. H., Smetacek, V. (eds.) Reports on Polar Research 65. Alfred Wegener Institute, Bremerhaven, p. $10-13$

Verlencar, X. N., Somasunder, K., Qasim, S. Z. (1990). Regeneration of nutrients and biological productivity in Antarctic waters. Mar. Ecol. Prog. Ser. 61, 41-59

Wheeler, P. A., Kokkinnakis, S. A. (1990). Ammonium recycling limits nutrate use in the oceanic subarctic Pacific. Limnol. Oceanogr. 35: $1267-1278$

Manuscript first received: July 1, 1991

Revised version accepted: November 13,1991 